\title{
MICROGLIA ARE NOT BRAIN MACROPHAGES?
}

\author{
Marin Zhelezov* and Anton B. Tonchev \\ Department of Anatomy and Cell Biology, Medical University, Varna, Bulgaria
}

Microglia are commonly referred to as the brain's macrophages, which leads to confusion due to the presence of several other macrophage populations in the central nervous system. The morphological, molecular and ontological differences between these cells are subtle. They need to be clearly defined in the light of the new evidence suggesting that microglia originate not in the bone marrow, but from yolk sac, or, possibly, pericyte progenitors. Recent paradigm shift redefines the specific roles of microglia during brain development, health and disease. Microglia have emerged as key players in important events such as neurogenesis, programmed cell death, elimination of synapses and remodeling of neural circuits. These novel discoveries imply a need for a better morphological and molecular differentiation of mononuclear phagocyte populations and their subtypes in the brain. This may improve our knowledge of their specific contributions and possible pharmacological manipulation in brain health and disease. Biomed Rev 2018; 29: 99-108

Keywords: brain, macrophages, microglia, monocyte-macrophage system, pericytes, epiblast, memory, disease

\section{INTRODUCTION: MACROPHAGE HETEROGENITY IN THE CENTRAL NERVOUS SYSTEM}

Microglia are the main mononuclear phagocytes of the brain and are commonly referred to as "brain tissue macrophages", similar to other tissue macrophages such as the Kupffer cells in the liver. However the central nervous system (CNS) contains several other populations of immune cells, including B-, T- and NK-cells, dendritic cells, as well as at least three separate groups of resident macrophages, namely, meningeal, perivascular and choroid plexus macrophages, which are strategically located at the interface between the parenchyma and the circulation (1-3). These other CNS macrophages were once virtually ignored, however recent evidence (4) has shed light onto their specific functions in the brain. It is virtually impossible to distinguish microglia from other brain macrophages and monocytes, entering from the blood based on morphological criteria alone (5-7). In addition, many of the markers that these cells express are overlapping (3). This challenge was recently addressed in comparative transcriptomic studies, aimed at identifying specific molecular signatures of the diverse populations of macrophages (8-13). Currently, microglial cells can be precisely distinguished from other

Received 25 November 2018, revised 17 December 2018, accepted 18 December 2018.

* Correspondence to: Dr Marin Zhelezov, Department of Anatomy and Cell Biology, Medical University, 55 Prof. Marin Drinov Str., BG-9002 Varna, Bulgaria. E-mail: marin.zhelezov@gmail.com 
brain macrophages via specific expression of transmembrane protein 119 (TMEM119), P2Y purinoceptor 12 (P2RY12) and Sal-like protein 1 (SALL1) $(9,12,14)$.

\section{INSIGHTS FROM ONTOGENY}

Originally it was thought that microglia arise from the neuroectoderm, a view which later changed in favor of a blood monocytic origin and dominated for decades (15). However, this was recently challenged by convincing evidence, demonstrating that microglia derive from the embryonic yolk sac (YS) (16-18). Yolk sac erythromyeloid precursors generate macrophages which migrate and colonize the embryonic brain $(19,20)$. It is also the site of origin of perivascular and meningeal macrophages. Interestingly, choroid plexus macrophages were shown to have dual embryonic and adult hematopoietic origins $(3,21)$. They are the only macrophage population in the brain that does not maintain its numbers in adulthood by self-renewal (21-24).

Despite the strong evidence for the YS origin of microglial progenitors, there was a long ongoing debate whether peripheral cells from the blood can enter the brain parenchyma and contribute to the microglial population. Originally, it was thought that, the CNS is an immune privileged site, protected by the blood-brain barrier (BBB) from cell entry from the circulation $(25,26)$. Indeed, experiments using parabiotic chimeric mice with shared circulation show that, under physiological conditions, there is a constant entry of monocytes to peripheral organs such as liver and spleen, but not into the brain (27). In addition, adult microglia can recover their numbers following genetic or chemical depletion $(22,28)$ and can maintain their population with little contribution from blood cells $(16,27,29,30)$.

It is considered that recruitment of circulating monocytes occurs only when the BBB is open, for example after irradiation or bone marrow transplantation $(3,15)$. Under such pathological conditions, bone marrow derived precursors can generate microglia-like cells (31-33) and, due to perceived functional similarity, were referred to as "blood-derived microglia", which has contributed to an ongoing confusion (5, 34-36). Recent evidence demonstrated that these infiltrating cells have unique functions which cannot be provided by resident microglial cells (37-39).

Mmonocyte-macrophage system, microglia and pericytes

A very important alternative hypothesis concerning the origin of the monocyte-macrophage system (MMS) is the presumption that all members of this system originate from a common embryonal pluripotent ancestor (3, 15, 30, 40-42). Sheng et al (30) presumed that all adult macrophages, resident or infiltrating, are derived from the fetal hematopoietic stem cells with the exception of microglia and partially epidermal Langerhans cells, which are yolk sac-derived. However, the hematopoietic stem cells are also epiblast derivatives, which have been migrated to the yolk sac and from there to the aortagonad-mesonephros region, the liver (Kupfer cells), the spleen, and the bone marrow $(42,43)$. Thus, the numerous variants of the microglia-macrophage system are the result of the different phases and places of development and differentiation of the cells with common embryonal origin.

In this respect, one may hypothesize that as common precursors of the MMS come very probably the embryonic pericyte progenitors and the pluripotent pericytes in adult vertebrates. There is strong evidence that pluripotent pericyte progenitor cells arise in the epiblast of the embryonal blastocyst $(21,30$, 44-46).

In the microvasculature the pericytes lie in periendothelial position within true microvascular niches as resting, reserve adult stem cells for tissue generation, maintenance, repair and regeneration (46). In fact, the pericytes can be considered as representants, respectively as the adult stem cells, of the embryonic epiblast in the adult, mature organism. Thus, it is noteworthy that the pericytes represent a highly immature form of pluripotent stem cells that maintain their phenotype throughout the whole life within the true microvascular niches.

Findings that pericytes possess macrophage properties (47-49) and are capable to build macrophages and microglia in the CNS (50-52) provide evidence that pericytes are able to transform themselves into microglial cells by virtue of an activation process in which the astrocytic neuroglia appears to play a decisive role.

The presumption that microglia may originate as progeny of activated pericytes is supported by newer studies demonstrating that microglial repopulation after experimental inhibitor cessation occurs by proliferation and differentiation of cells expressing nestin, which, interestingly, is also expressed by pericytes as well as their progeny $(53,54)$. The same process was observed in an experiment with regenerating testicular Leydig cells which originate from nestin-expressing pericytes (55).

In this respect, very informative are the electron microscopic results illustrating that some microglia cells lie within the expansions of basal lamina of capillaries (pericytal microglia) (56). There is evidence that these cells can break out of 
their basal lamina enclosure and enter the brain neuropil and were thus termed interstitial microglia. It seems likely that these authors were unable to observe the transdifferentiation (a kind of metaplasia) of the pericitic transit amplifying cells in microglia. These results provide additional evidence that the activated pericytes, situated within the true microvascular niches, may be the ancestors of the microglia.

There is also evidence for a close resemblance between the pericytes and the microglia concerning not only their location, but also marker substances, resting and activation conditions, plasticity and origin (52). As well as their close interrelationship with the developing and differentiated vasculature reinforces the presumption that both cell types may have similar origin.

Taken together, there is a real possibility that all members of MMS, including pericytes, originate from the same ancestor, namely the embryonal epiblast. The epiblast stem cells migrate via the mesoderm toward different regions which are able to undergo embryonal vasculogenesis and to generate primitive vascular plexuses (e.g. yolk sac and dorsal aorta) $(57,58)$. These stem cells (are also pericyte progenitors) become distributed throughout the whole organism, where remain enclosed in the microvascular niches as resting adult stem cells. In the brain, via the process of transdifferentiation and maturation, variable forms of microglia and other cell phenotypes may arise.
The described differences in ontogeny can provide further insights for the functional differentiation of CNS myeloid cells. Importantly, in the mouse, immature microglia colonizes the embryonic brain at approximately day 9.5, which coincides with neurogenesis, before astrocytes and oligodendrocytes are generated (59). This allows microglia to participate in a number of key developmental events in the CNS, as discussed below.

\section{MICROGLIAL ROLES DURING DEVELOPMENT AND DISEASE}

Microglia constitute around $10 \%$ of all cells in the brain (60). They exhibit a number of morphological states, associated with changes in function and gene expression. During development these cells adopt an "amoeboid" morphology with large, round body and short, thick branches, showing higher levels of phagocytic activity. In contrast, adult microglia have a small body with numerous, fine, highly branched processes (61). Under pathological conditions, secretory changes in microglia are accompanied with morphological changes similar to those during development (Fig. 1). These activated cells were traditionally classified as either M1 ("toxic") or M2 ("protective") type. Newer evidence has challenged this view, demonstrating a continuum of microglial forms with overlapping gene expression (62).

Once microglial cells were thought to remain quiescent under physiological conditions, maintaining a "resting" state and only "activate" in pathological processes. Thus, microglia
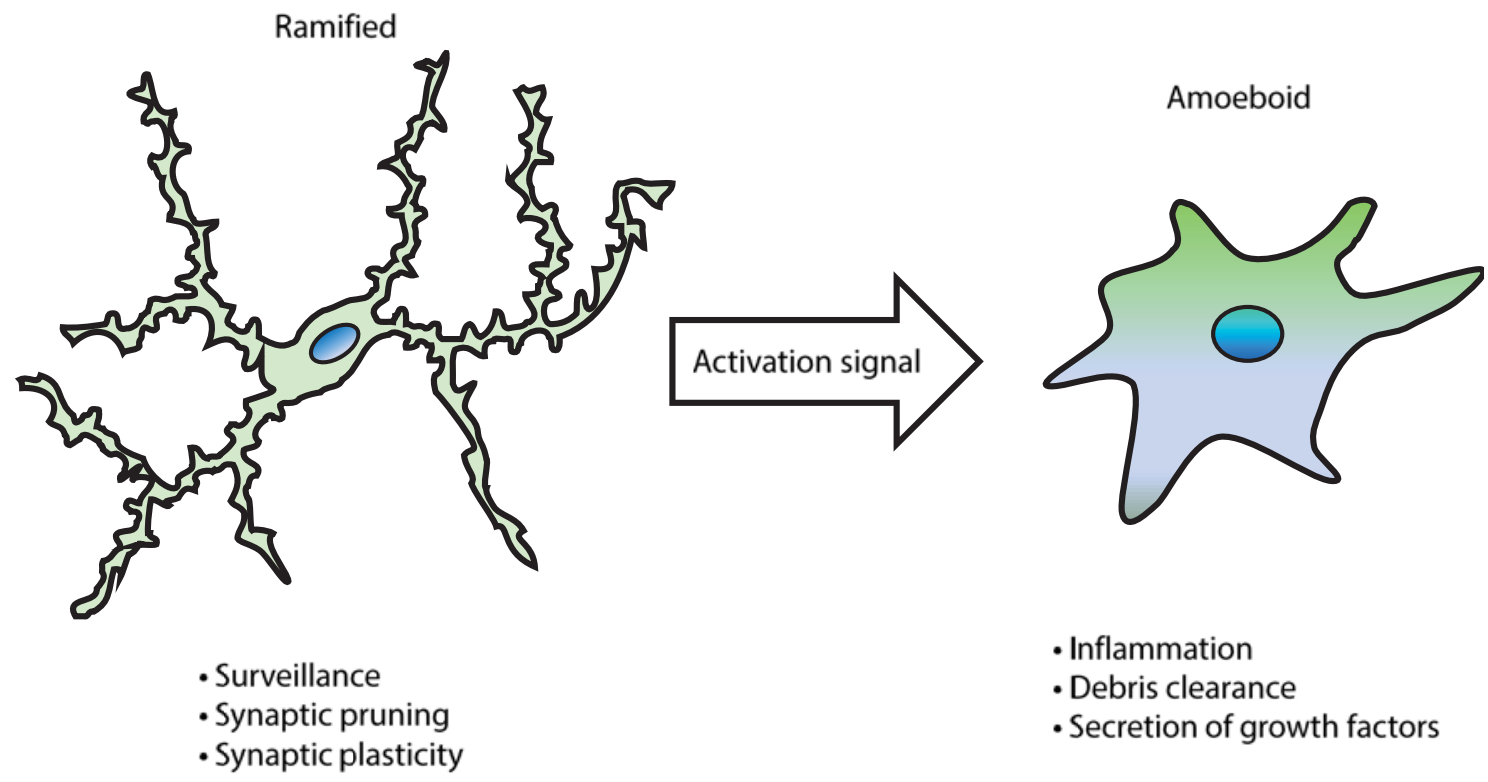

Figure 1. Functions of microglia at different stages of activation. Ramified microglia is primarily involved in immune surveillance, as well as synaptic pruning and plasticity. Under pathological conditions it transforms to an amoeboid form with a pro-inflammatory profile, including secretion of growth factors and clearance of debris. 
were thought to play a primarily passive role in brain homeostasis and were long ignored. However, a number of recent studies showed substantial microglial involvement in a large number of key events during both normal development and disease, which has led to a paradigm shift, placing microglia as "central players" in brain disease (63).

\section{Immune surveillance}

Time-lapse recordings demonstrated that microglia are highly dynamic cells, which actively survey their cell-specific territory and can scan the entire brain parenchyma in just a few hours (64). Their fine processes continuously contact neural elements, including axons and dendritic spines, being able to significantly change their motility, following extracellular stimuli such as neuronal activity $(65,66)$ and the release of neurotransmitters $(65,67)$. Indeed, it has been shown that microglia preferentially contact and neurons with higher levels of activity, thus attenuating their action (65).

\section{Synaptic pruning during development}

During CNS development microglia contribute to the process of synaptic pruning by engulfing synapses, thus shaping neuronal circuits (68-70). Evidence from the mouse visual system has demonstrated neuronal activity and sensory experience as important factors for this process $(68,70)$. Molecules of the classical-complement cascade have been recognized as key players in microglial synaptic modification (70-73). Microglial cells express a $\mathrm{C} 3$ receptor and are able to phagocytose immature C3-expressing synapses $(71,73)$. Importantly, disruption of microglial synaptic pruning during development results in defects in neuronal wiring (70).

\section{Programmed neuronal death during development}

The excess neurons produced by neurogenesis during development and in the adult die via programmed cell death, consequently being phagocytosed by microglial cells $(74,75)$. Interestingly, microglia do not simply take a passive scavenging role but can induce neuronal apoptosis themselves via the release of a variety of neurotoxic factors (76-79).

\section{Learning and memory}

Microglial involvement in neurogenesis and synaptic modification suggests important roles of these cells in two key processes associated with learning and memory, namely adult neurogenesis $(80,81)$ and activity-dependent, long-term synaptic plasticity (82) which has been supported by a growing number of studies (83-92).

\section{Role in disease}

It is now considered that microglia contribute to both neurodevelopmental and neurodegenerative disease. Experimental deletion of microglia-specific receptors in rodents leads to defects of the laminar positioning of neocortical interneurons, as well as the outgrowth of forebrain dopaminergic axons (93). Perturbed synaptic pruning and modification by microglia during development may disrupt connectivity in ways, associated with diseases such as autism and schizophrenia (94). This is supported by postmortem studies, demonstrating several microglial alterations in brains from individuals with autism, especially in regions, involved in executive function control, such as the dorsolateral prefrontal cortex (95-97).

Microglia are key players in neuroinflammation, which is associated with virtually all neurodegenerative diseases (98). A staggering amount of evidence has elucidated multiple mechanisms of microglial involvement in conditions such as Alzheimer's disease, amyotrophic lateral sclerosis, multiple sclerosis, glaucoma, and neuropathic pain $(59,63)$.

\section{FUNCTIONS OF RESIDENT MACROPHAGES IN THE CNS}

The resident CNS macrophages, namely, perivascular, meningeal and choroid plexus macrophages are poorly understood. Perivascular macrophages share similarities with microglia, in terms of their transcriptional profile and marker expression, including Iba1, CD11b, CX3CR1 and others (21, 99). However, their transcriptional profile differentiates them from monocytes in blood (21).

Under normal conditions they continuously extend and retract numerous processes along blood vessels, suggesting a role in immune surveillance $(2,21,100)$, whereas under inflammatory conditions they may regulate recruitment of leucocytes from the periphery (101). In addition, they may play a role in BBB establishment (102).

Yolk sac-derived resident macrophages have been described in both mouse and human meninges (21). Little is known for their physiologic functions. Peripheral macrophages play a role in regulating the proliferation of lymphatic endothelial cells and it is thought that meningeal macrophages have similar functions, although it is now known whether they are part of the newly discovered brain glymphatic system $(2,103)$. There is evidence that, under experimental conditions, meningeal macrophages, together with dendritic cells, are involved in antigen presentation to $\mathrm{T}$ cells during autoimmune diseases $(2,104)$.

Although choroid plexus macrophages are poorly under- 
stood, their specific location close to the ependymal cells' microvilli (21) suggests involvement in cerebrospinal fluid release. Interestingly, they are present in circumventricular organs (CVOs) as well (105). These latter organs are highly vascularized special structures, located close to the brain ventricles. They contain fenestrated capillaries and lack a blood-brain barrier, thus performing both sensory and secretory roles by sampling the blood and releasing substances into the cerebrospinal fluid $(105,106)$.

Table 1 provides examples of microglial and brain macrophage functions.

\section{CONCLUSION}

In light of microglia's recently discovered crucial roles during development and brain disease, there is a need to elucidate the key structural and functional differences between these heterogenous populations of cells. This brings the promise of precise targeted pharmacological interventions in the future to modulate CNS function and pathology.

\section{ACKNOWLEDGEMENTS}

The authors' sincere thanks are for Professor Michail S. Davidoff (Institute of Anatomy, University Medical Center Hamburg - Eppendorf, Hamburg, Germany) for his creative reading of the manuscript of the present Dance round.

\section{CONFLICT OF INTERESTS}

There are no conflicts of interests to disclose.

\section{REFERENCES}

1. Korin B, Ben-Shaanan TL, Schiller M, Dubovik T, AzulayDebby H, Boshnak NT, et al. High-dimensional, single-cell characterization of the brain's immune compartment. Nat Neurosci 2017;20(9):1300-1309. DOI: 10.1038/nn.4610

2. Lopez-Atalaya JP, Askew KE, Sierra A, Gomez-Nicola D. Development and maintenance of the brain's immune toolkit: Microglia and non-parenchymal brain macrophages: Development and maintenance of the brain's immune toolkit. Dev Neurobiol 2017;78: 561-579. DOI: 10.1002/ dneu.22545

3. Prinz M, Erny D, Hagemeyer N. Ontogeny and homeostasis of CNS myeloid cells. Nat Immunol 2017;18(4):385392. DOI: $10.1038 /$ ni.3703

4. Herz J, Filiano AJ, Smith A, Yogev N, Kipnis J. Myeloid cells in the central nervous system. Immunity 2017;46(6):943-956. DOI: 10.1016/j.immuni.2017.06.007

5. Priller J, Flügel A, Wehner T, Boentert M, Haas CA, Prinz M, et al. Targeting gene-modified hematopoietic cells to the central nervous system: use of green fluorescent protein uncovers microglial engraftment. Nat Med 2001;7(12):1356-1361. DOI: 10.1038/nm1201-1356

6. Djukic M. Circulating monocytes engraft in the brain, differentiate into microglia and contribute to the pathology following meningitis in mice. Brain 2006;129(9):2394403. DOI: $10.1093 /$ brain/awl206

7. Mildner A, Mack M, Schmidt H, Brück W, Djukic M, Zabel MD, et al. CCR2+Ly-6Chi monocytes are crucial for the effector phase of autoimmunity in the central nervous system. Brain 2009;132(9):2487-500. DOI:10.1093/ brain/awp144

Table 1. A summary of microglial and brain macrophage functions

\begin{tabular}{|c|c|c|c|}
\hline Microglia & $\begin{array}{l}\text { Perivascular } \\
\text { macrophages }\end{array}$ & $\begin{array}{l}\text { Meningeal } \\
\text { macrophages }\end{array}$ & $\begin{array}{l}\text { Choroid plexus } \\
\text { macrophages }\end{array}$ \\
\hline $\begin{array}{l}\text { Development: } \\
\text { - Immune surveillance } \\
\text { - Synaptic pruning } \\
\text { - Regulate laminar positioning of neurons } \\
\text { - Promote cell death }\end{array}$ & \multirow[t]{2}{*}{$\begin{array}{l}\text { - Immune surveillance } \\
\text { - Regulate recruitment } \\
\text { of leucocytes } \\
\text { - BBB establishment }\end{array}$} & \multirow[t]{2}{*}{$\begin{array}{l}\text { - Regulate proliferation } \\
\text { of lymphatic } \\
\text { endothelial cells } \\
\text { - Antigen presentation }\end{array}$} & \multirow[t]{2}{*}{$\begin{array}{l}\text { - } \text { cerebrospinal fluid } \\
\text { release } \\
\text { - role in circumventricular } \\
\text { organs }\end{array}$} \\
\hline $\begin{array}{l}\text { Adult: } \\
\text { - Immune surveillance } \\
\text { - Synaptic plasticity } \\
\text { - Monitor neuronal activity } \\
\text { - Praticipate in neuroinlammation } \\
\text { - Clearance of debris }\end{array}$ & & & \\
\hline
\end{tabular}


8. Gautier EL, Shay T, Miller J, Greter M, Jakubzick C, Ivanov $\mathrm{S}$, et al. Gene-expression profiles and transcriptional regulatory pathways that underlie the identity and diversity of mouse tissue macrophages. Nat Immunol 2012;13(11):1118-1128. DOI: 10.1038/ni.2419

9. Butovsky O, Jedrychowski MP, Moore CS, Cialic R, Lanser AJ, Gabriely G, et al. Identification of a unique TGF- $\beta$-dependent molecular and functional signature in microglia. Nat Neurosci 2014;17(1):131-43. DOI: 10.1038/nn.3599

10. Gosselin D, Link VM, Romanoski CE, Fonseca GJ, Eichenfield DZ, Spann NJ, et al. Environment drives selection and function of enhancers controlling tissue-specific macrophage identities. Cell 2014;159(6):1327-40. DOI: 10.1016/j.cell.2014.11.023

11. Lavin Y, Winter D, Blecher-Gonen R, David E, KerenShaul H, Merad M, et al. Tissue-resident macrophage enhancer landscapes are shaped by the local microenvironment. Cell 2014;159(6):1312-1326. DOI: 10.1016/j. cell.2014.11.018

12. Bennett ML, Bennett FC, Liddelow SA, Ajami B, Zamanian JL, Fernhoff NB, et al. New tools for studying microglia in the mouse and human CNS. Proc Natl Acad Sci USA 2016;113(12):E1738-1746. DOI: 10.1073/ pnas. 1525528113

13. Crotti A, Ransohoff RM. Microglial physiology and pathophysiology: Insights from genome-wide transcriptional profiling. Immunity 2016;44(3):505-515. DOI: 10.1016/j. immuni.2016.02.013

14. Buttgereit A, Lelios I, Yu X, Vrohlings M, Krakoski NR, Gautier EL, et al. Sall1 is a transcriptional regulator defining microglia identity and function. Nat Immunol 2016;17(12):1397-1406. DOI: 10.1038/ni.3585

15. Ginhoux F, Lim S, Hoeffel G, Low D, Huber T. Origin and differentiation of microglia. Front Cell Neurosci 2013;7:45. DOI: 10.3389/fncel.2013.00045

16. Ginhoux F, Greter M, Leboeuf M, Nandi S, See P, Gokhan S, et al. Fate mapping analysis reveals that adult microglia derive from primitive macrophages. Science 2010;330(6005):841-845. DOI: 10.1126/science.1194637

17. Hoeffel G, Ginhoux F. Ontogeny of tissue-resident macrophages. Front Immunol 2015; 6:486. DOI: 10.3389/ fimmu.2015.00486

18. Ginhoux F, Guilliams M. Tissue-resident macrophage ontogeny and homeostasis. Immunity 2016;44(3):439-449. DOI: 10.1016/j.immuni.2016.02.024
19. Kierdorf K, Erny D, Goldmann T, Sander V, Schulz C, Perdiguero EG, et al. Microglia emerge from erythromyeloid precursors via $\mathrm{Pu}$. 1-and Irf8-dependent pathways. Nat Neurosci 2013;16(3):273-80. DOI: 10.1038/nn.3318

20. Gomez E, Klapproth K, Schulz C, Busch K, Azzoni E, Crozet L, et al. Tissue-resident macrophages originate from yolk-sac-derived erythro-myeloid progenitors. $\mathrm{Na}$ ture 2015;518(7540):547-551. DOI: 10.1038/nature13989

21. Goldmann T, Wieghofer P, Jordão MJC, Prutek F, Hagemeyer N, Frenzel K, et al. Origin, fate and dynamics of macrophages at central nervous system interfaces. Nat Immunol 2016;17(7):797-805. DOI: 10.1038/ni.3423

22. Askew K, Li K, Olmos-Alonso A, Garcia-Moreno F, Liang Y, Richardson P, et al. Coupled Proliferation and Apoptosis Maintain the Rapid Turnover of Microglia in the Adult Brain. Cell Rep 2017;18(2):391-405. DOI: 10.1016/j.celrep.2016.12.041

23. Réu P, Khosravi A, Bernard S, Mold JE, Salehpour M, Alkass K, et al. The Lifespan and Turnover of Microglia in the Human Brain. Cell Rep 2017;20(4):779-784. DOI: 10.1016/j.celrep.2017.07.004

24. Tay TL, Mai D, Dautzenberg J, Fernández-Klett F, Lin G, Sagar, et al. A new fate mapping system reveals contextdependent random or clonal expansion of microglia. Nat Neurosci. 2017;20(6):793-803. DOI: 10.1038/nn.4547

25. Wilson EH, Weninger W, Hunter CA. Trafficking of immune cells in the central nervous system. J Clin Invest 2010;120(5):1368-1379. DOI: 10.1172/JCI41911

26. Ransohoff RM, Engelhardt B. The anatomical and cellular basis of immune surveillance in the central nervous system. Nat Rev Immunol 2012;12(9):623-35. DOI: 10.1038/ nri3265

27. Ajami B, Bennett JL, Krieger C, Tetzlaff W, Rossi FMV. Local self-renewal can sustain CNS microglia maintenance and function throughout adult life. Nat Neurosci 2007;10(12):1538-43. DOI: 10.1038/nn2014

28. Bruttger J, Karram K, Wörtge S, Regen T, Marini F, Hoppmann N, et al. Genetic Cell Ablation Reveals Clusters of Local Self-Renewing Microglia in the Mammalian Central Nervous System. Immunity 2015;43(1):92-106. DOI: 10.1016/j.immuni.2015.06.012

29. Hashimoto D, Chow A, Noizat C, Teo P, Beasley MB, Leboeuf M, et al. Tissue-Resident Macrophages Self-Maintain Locally throughout Adult Life with Minimal Contribution from Circulating Monocytes. Immunity 2013;38(4):792804. DOI: 10.1016/j.immuni.2013.04.004 
30. Sheng J, Ruedl C, Karjalainen K. Most Tissue-Resident Macrophages Except Microglia Are Derived from Fetal Hematopoietic Stem Cells. Immunity 2015;43(2):382393. DOI: 10.1016/j.immuni.2015.07.016

31. Flügel A, Bradl M, Kreutzberg GW, Graeber MB. Transformation of donor-derived bone marrow precursors into host microglia during autoimmune CNS inflammation and during the retrograde response to axotomy. J Neurosci Res 2001;66(1):74-82. DOI: 10.1002/jnr.1198

32. Mildner A, Schmidt H, Nitsche M, Merkler D, Hanisch U-K, Mack M, et al. Microglia in the adult brain arise from Ly-6ChiCCR2+ monocytes only under defined host conditions. Nat Neurosci 2007;10(12):1544-53. DOI: $10.1038 / \mathrm{nn} 2015$

33. Varvel NH, Grathwohl SA, Baumann F, Liebig C, Bosch A, Brawek B, et al. Microglial repopulation model reveals a robust homeostatic process for replacing CNS myeloid cells. Proc Natl Acad Sci USA 2012;109(44):1815018155. DOI: 10.1073/pnas.1210150109

34. Eglitis MA, Mezey É. Hematopoietic cells differentiate into both microglia and macroglia in the brains of adult mice. Proc Natl Acad Sci USA 1997;94(8):4080-4085. DOI: 10.1073/pnas.94.8.4080

35. Bechmann I, Goldmann J, Kovac AD, Kwidzinski E, Simbürger E, Naftolin F, et al. Circulating monocytic cells infiltrate layers of anterograde axonal degeneration where they transform into microglia. FASEB J 2005;19(6):647649. DOI: 10.1096/fj.04-2599fje

36. Simard AR, Soulet D, Gowing G, Julien J-P, Rivest $\mathrm{S}$. Bone marrow-derived microglia play a critical role in restricting senile plaque formation in Alzheimer's disease. Neuron 2006;49(4):489-502. DOI: 10.1016/j. neuron.2006.01.022

37. Shechter R, London A, Varol C, Raposo C, Cusimano $\mathrm{M}$, Yovel G, et al. Infiltrating Blood-Derived Macrophages Are Vital Cells Playing an Anti-inflammatory Role in Recovery from Spinal Cord Injury in Mice. PLoS Med. 2009;6(7):e1000113. DOI: 10.1371/journal. pmed.1000113

38. London A, Itskovich E, Benhar I, Kalchenko V, Mack M, Jung S, et al. Neuroprotection and progenitor cell renewal in the injured adult murine retina requires healing monocyte-derived macrophages. J Exp Med. 2011;208(1):23-39. DOI: 10.1084/jem.20101202

39. Shechter R, Raposo C, London A, Sagi I, Schwartz M. The Glial Scar-Monocyte Interplay: A Pivotal Resolution Phase in Spinal Cord Repair. PLoS ONE. 2011;6(12):e27969. DOI: 10.1371/journal.pone.0027969

40. Gardner RL, Rossant J. Investigation of the fate of 4.5 day post-coitum mouse inner cell mass cells by blastocyst injection. J Embryol Exp Morphol 1979; 52: 141-152

41. Fogg DK, Sibon C, Miled C, Jung S, Aucouturier P, Littman DR, et al. A clonogenic bone barrow progenitor specific for macrophages and dendritic cells. Science 2006; 311(5757):83-87. DOI:10.1126/science.1117729

42. Ginhoux F, Prinz M. Origin of Microglia: Current Concepts and Past Controversies. Cold Spring Harb Perspect Biol 2015;7:a020537. DOI:10.1101/cshperspect.a020537

43. Perdiguero E, Klapproth K, Schulz C, Busch K, Azzoni $\mathrm{E}$, Crozet L, et al. Tissue-resident macrophages originate from yolk-sac-derived erythro-myeloid progenitors. $\mathrm{Na}$ ture 2015; 518(7540): 547-551. DOI:10.1038/nature13989

44. Spittau B. Aging microglia - phenotypes, functions and implications for age-related neurodegenerative diseases. Front Aging Neurosci 2017; 9:194. DOI: 10.3389/ fnagi.2017.00194

45. Davidoff MS. The Leydig cells of the testis originate from the microvascular pericytes. Biomed Rev 2017; 28: 5-25. DOI: http://dx.doi.org/10.14748/bmr.v28.4448

46. Virgintino D, Girolamo F, Errede M, Capobianco C, Robertson D, Stallcup WB, et al. (2007) An intimate interplay between precocious, migrating pericytes and endothelial cells governs human fetal brain angiogenesis. Angiogenesis 10(1): 35-45. DOI: 10.1007/s10456-006-9061-x

47. Balabanov R, Washington R, Wagnerova J, Dore-Duffy P. CNS microvascular pericytes express macrophagelike function, cell surface integrin $\alpha \mathrm{M}$, and macrophage marker ED-2. Microvasc Res 1996; 52(2): 127-142. DOI: 10.1006/mvre.1996.0049

48. Thomas WE. Brain macrophages: on the role of pericytes and perivascular cells. Brain Res Brain Res Rev 1999; 31(1): 42-57. DOI:10.1016/S0165-0173(99)00024-7

49. Guillemin GJ, Brew BJ. Microglia, macrophages perivascular macrophages, and pericytes: a review of function and identification. J Leukoc Biol 2004; 75(3): 388-3297. DOI: 10.1189/jlb.0303114

50. Andriezen WL. The neuroglia elements in the human brain. Br Med J 1893; 2:227-230

51. Rezaie P, Hanisch U-K. Historical Content, Chapter 2. In: M.-È. Tremblay, A. Sierra, editors Microglia in Health and Disease. Springer Science+Business Media New York 2014; pp 7-46. DOI 10.1007/978-1-4939-1429-6_2 
52. Barón M, Gallego A. The relation of the microglia with the pericytes in the cat cerebral cortex. Z. Zellforsch 1972;128(1): 42-57. DOI:10.1007/BF00306887

53. Elmore MR, Najafi AR, Koike MA, Dagher NN, Spangenberg EE, Rice RA, et al. Colony-stimulating factor 1 receptor signaling is necessary for microglia viability, unmasking a microglia progenitor cell in the adult brain. Neuron 2014; 82(2):380-397. DOI: 10.1016/j. neuron.2014.02.040

54. Pacini S, Petrini I. Are MSCs angiogenic cells? New insights on human nestin-positive bone-marrow-derived multipotent cells. Front Cell Dev Biol 2014;2, Article 20. DOI: $10.3389 /$ fcell.2014.00020

55. Davidoff MS, Middendorff R, Enikolopov G, Rietmacher D, Holstein AF, Müller D. Progenitor cells of the testosterone-producing Leydig cells revealed. J Cell Biol 2004;167: 935-944. DOI: 10.1083/jcb.200409107

56. Mori S, Leblond CP. Identification of microglia in light and electron microscopy. J Comp Neurol 1969;135(1): $57-79$

57. Eichmann A, Bouvrée K, Pardanaud L. Vasculogenesis and angiogenesis in development. In: D Marmé, N Fusenig, editors. Tumor Angiogenesis. Basic Mechansims and Cancer Therapy. Springer, 2008, pp. 31-45

58. Arora R, Papaioannou VE. The murine allantois: a model system for the study of blood vessel formation. Blood 2012; 120(13): 2562-2572. DOI:10.1182/ blood-2012-03-390070

59. Li Q, Barres BA. Microglia and macrophages in brain homeostasis and disease. Nat Rev Immunol 2018;18(4):225242. DOI: $10.1038 /$ nri.2017.125

60. Aguzzi A, Barres BA, Bennett ML. Microglia: scapegoat, saboteur, or something else? Science 2013;339(6116):156161.

61. Zusso M, Methot L, Lo R, Greenhalgh AD, David S, Stifani S. Regulation of Postnatal Forebrain Amoeboid Microglial Cell Proliferation and Development by the Transcription Factor Runx1. J Neurosci. 2012;32(33):11285-98. DOI: 10.1523/JNEUROSCI.6182-11.2012

62. Ransohoff RM. A polarizing question: do M1 and M2 microglia exist? Nat Neurosci. 2016;19(8):987-91. DOI: $10.1038 / \mathrm{nn} .4338$

63. Salter MW, Stevens B. Microglia emerge as central players in brain disease. Nat Med. 2017;23(9):1018-27. DOI: 10.1038/nm.4397

64. Nimmerjahn A. Resting Microglial Cells Are Highly
Dynamic Surveillants of Brain Parenchyma in Vivo. Science 2005;308(5726):1314-1318. DOI: 10.1126/science. 1110647

65. Li Y, Du X, Liu C, Wen Z, Du J. Reciprocal Regulation between Resting Microglial Dynamics and Neuronal Activity In Vivo. Dev Cell 2012;23(6):1189-202. DOI: 10.1016/j.devcel.2012.10.027

66. Abiega O, Beccari S, Diaz-Aparicio I, Nadjar A, Layé S, Leyrolle Q, et al. Neuronal Hyperactivity Disturbs ATP Microgradients, Impairs Microglial Motility, and Reduces Phagocytic Receptor Expression Triggering Apoptosis/Microglial Phagocytosis Uncoupling. PLOS Biol 2016;14(5):e1002466. DOI: 10.1371/journal. pbio. 1002466

67. Davalos D, Grutzendler J, Yang G, Kim JV, Zuo Y, Jung $\mathrm{S}$, et al. ATP mediates rapid microglial response to local brain injury in vivo. Nat Neurosci. 2005;8(6):752-758. DOI: $10.1038 / \mathrm{nn} 1472$

68. Tremblay M-È, Lowery RL, Majewska AK. Microglial Interactions with Synapses Are Modulated by Visual Experience. PLoS Biol. 2010;8(11):e1000527. DOI: 10.1371/ journal.pbio.1000527

69. Paolicelli RC, Bolasco G, Pagani F, Maggi L, Scianni M, Panzanelli P, et al. Synaptic Pruning by Microglia Is Necessary for Normal Brain Development. Science. 2011;333(6048):1456-1458. DOI: 10.1126/science. 1202529

70. Schafer DP, Lehrman EK, Kautzman AG, Koyama R, Mardinly AR, Yamasaki R, et al. Microglia Sculpt Postnatal Neural Circuits in an Activity and ComplementDependent Manner. Neuron 2012;74(4):691-705. DOI: 10.1016/j.neuron.2012.03.026

71. Stevens B, Allen NJ, Vazquez LE, Howell GR, Christopherson KS, Nouri N, et al. The Classical Complement Cascade Mediates CNS Synapse Elimination. Cell 2007;131(6):1164-1178. DOI: 10.1016/j. cell.2007.10.036

72. Hong S, Dissing-Olesen L, Stevens B. New insights on the role of microglia in synaptic pruning in health and disease. Curr Opin Neurobiol 2016;36:128-134. DOI: 10.1016/j.conb.2015.12.004

73. Lui H, Zhang J, Makinson SR, Cahill MK, Kelley KW, Huang H-Y, et al. Progranulin Deficiency Promotes Circuit-Specific Synaptic Pruning by Microglia via Complement Activation. Cell 2016;165(4):921-935. DOI: 10.1016/j.cell.2016.04.001 
74. Marín-Teva JL, Cuadros MA, Martín-Oliva D, Navascués J. Microglia and neuronal cell death. Neuron Glia Biol 2011;7(01):25-40. DOI: 10.1017/S1740925X12000014

75. Brown GC, Neher JJ. Microglial phagocytosis of live neurons. Nat Rev Neurosci. 2014;15(4):209. DOI: 10.1038/ nrn3710

76. Frade JM, Barde Y-A. Microglia-derived nerve growth factor causes cell death in the developing retina. Neuron 1998;20(1):35-41. DOI: 10.1016/S0896-6273(00)80432-8

77. Marın-Teva JL, Dusart I, Colin C, Gervais A, Van Rooijen N, Mallat M. Microglia promote the death of developing Purkinje cells. Neuron 2004;41(4):535-547. DOI: 10.1016/S0896-6273(04)00069-8

78. Sedel F. Macrophage-Derived Tumor Necrosis Factor, an Early Developmental Signal for Motoneuron Death. $J$ Neurosci. 2004;24(9):2236-2246. DOI: 10.1523/JNEUROSCI.4464-03.2004

79. Wakselman S, Bechade C, Roumier A, Bernard D, Triller A, Bessis A. Developmental Neuronal Death in Hippocampus Requires the Microglial CD11b Integrin and DAP12 Immunoreceptor. J Neurosci 2008;28(32):81388143. DOI: 10.1523/JNEUROSCI.1006-08.2008

80. Zhao C, Deng W, Gage FH. Mechanisms and Functional Implications of Adult Neurogenesis. Cell 2008;132(4):645-660. DOI: 10.1016/j.cell.2008.01.033

81. Akers KG, Martinez-Canabal A, Restivo L, Yiu AP, De Cristofaro A, Hsiang H-L, et al. Hippocampal Neurogenesis Regulates Forgetting During Adulthood and Infancy. Science. 2014;344(6184):598-602. DOI: 10.1126/science. 1248903

82. Bliss TVP, Collingridge GL, Morris RGM. Synaptic plasticity in health and disease: introduction and overview. Philos Trans R Soc B Biol Sci 2013;369(1633):20130129_ 20130129. DOI: $10.1098 /$ rstb.2013.0129

83. Sierra A, Encinas JM, Deudero JJP, Chancey JH, Enikolopov G, Overstreet-Wadiche LS, et al. Microglia Shape Adult Hippocampal Neurogenesis through Apoptosis-Coupled Phagocytosis. Cell Stem Cell 2010;7(4):483495. DOI: 10.1016/j.stem.2010.08.014

84. Bachstetter AD, Morganti JM, Jernberg J, Schlunk A, Mitchell SH, Brewster KW, et al. Fractalkine and CX3CR1 regulate hippocampal neurogenesis in adult and aged rats. Neurobiol Aging 2011;32(11):2030-2044. DOI: 10.1016/j.neurobiolaging.2009.11.022

85. Rogers JT, Morganti JM, Bachstetter AD, Hudson CE, Peters MM, Grimmig BA, et al. CX3CR1 Deficiency Leads to Impairment of Hippocampal Cognitive Function and Synaptic Plasticity. J Neurosci 2011;31(45):16241-16250. DOI: 10.1523/JNEUROSCI.3667-11.2011

86. Tremblay M-E, Stevens B, Sierra A, Wake H, Bessis A, Nimmerjahn A. The Role of Microglia in the Healthy Brain. J Neurosci 2011;31(45):16064-16069. DOI: 10.1523/JNEUROSCI.4158-11.2011

87. Gemma C, Bachstetter AD. The role of microglia in adult hippocampal neurogenesis. Front Cell Neurosci 2013;7:229. DOI: 10.3389/fncel.2013.00229

88. Koeglsperger T, Li S, Brenneis C, Saulnier JL, Mayo $\mathrm{L}$, Carrier Y, et al. Impaired glutamate recycling and GluN2B-mediated neuronal calcium overload in mice lacking TGF- $\beta 1$ in the CNS: Tgf- $\beta 1$ and hippocampal glutamate homeostasis. Glia 2013;61(6):985-1002. DOI: 10.1002/glia.22490

89. Parkhurst CN, Yang G, Ninan I, Savas JN, Yates JR, Lafaille JJ, et al. Microglia Promote Learning-Dependent Synapse Formation through Brain-Derived Neurotrophic Factor. Cell. 2013;155(7):1596-609. DOI: 10.1016/j. cell.2013.11.030

90. Schafer DP, Lehrman EK, Stevens B. The "quad-partite" synapse: Microglia-synapse interactions in the developing and mature CNS. Glia 2013;61(1):24-36. DOI: 10.1002/ glia.22389

91. Sipe GO, Lowery, RL, Tremblay M-è, Kelly EA, Lamantia CE, Majewska AK. Microglial P2Y12 is necessary for synaptic plasticity in mouse visual cortex. Nat Commun 2016;7:10905. DOI: 10.1038/ncomms10905

92. George J, Cunha RA, Mulle C, Amédée T. Microglia-derived purines modulate mossy fibre synaptic transmission and plasticity through $\mathrm{P}_{2} \mathrm{X}_{4}$ and $\mathrm{A}_{1}$ receptors. Maccaferri G, editor. Eur J Neurosci 2016;43(10):1366-1378. DOI: 10.1111/ejn.13191

93. Squarzoni P, Oller G, Hoeffel G, Pont-Lezica L, Rostaing $\mathrm{P}$, Low D, et al. Microglia Modulate Wiring of the Embryonic Forebrain. Cell Rep 2014;8(5):1271-1279. DOI: 10.1016/j.celrep.2014.07.042

94. Penzes P, Cahill ME, Jones KA, VanLeeuwen J-E, Woolfrey KM. Dendritic spine pathology in neuropsychiatric disorders. Nat Neurosci 2011;14(3):285-293. DOI: 10.1038/nn.2741

95. Vargas DL, Nascimbene C, Krishnan C, Zimmerman AW, Pardo CA. Neuroglial activation and neuroinflammation in the brain of patients with autism. Ann Neurol 2005;57(1):67-81. DOI: 10.1002/ana.20315 
96. Morgan JT, Chana G, Pardo CA, Achim C, Semendeferi K, Buckwalter J, et al. Microglial Activation and Increased Microglial Density Observed in the Dorsolateral Prefrontal Cortex in Autism. Biol Psychiatry 2010;68(4):368-376. DOI: 10.1016/j.biopsych.2010.05.024

97. Tetreault NA, Hakeem AY, Jiang S, Williams BA, Allman E, Wold BJ, et al. Microglia in the Cerebral Cortex in Autism. J Autism Dev Disord 2012;42(12):2569-2584. DOI: $10.1007 / \mathrm{s} 10803-012-1513-0$

98. Colonna M, Butovsky O. Microglia Function in the Central Nervous System During Health and Neurodegeneration. Annu Rev Immunol 2017;35(1):441-468. DOI: 10.1146/annurev-immunol-051116-052358

99. Sierra A, Gottfried-Blackmore AC, McEwen BS, Bulloch K. Microglia derived from aging mice exhibit an altered inflammatory profile. Glia 2007;55(4):412-424. DOI: 10.1002/glia.20468

100. Daneman R. The blood-brain barrier in health and disease. Ann Neurol 2012;72(5):648-672. DOI: 10.1002/ ana. 23648

101. Polfliet MMJ, Zwijnenburg PJG, van Furth AM, van der Poll T, Dopp EA, Renardel de Lavalette C, et al. Meningeal and Perivascular Macrophages of the Central
Nervous System Play a Protective Role During Bacterial Meningitis. J Immunol 2001;167(8):4644-4650. DOI: 10.1128/CMR.17.4.942-964.2004

102. Yamamoto S, Muramatsu M, Azuma E, Ikutani M, Nagai Y, Sagara H, et al. A subset of cerebrovascular pericytes originates from mature macrophages in the very early phase of vascular development in CNS. Sci Rep 2017;7(1):3855. DOI: 10.1038/s41598-017-03994-1

103. Louveau A, Smirnov I, Keyes TJ, Eccles JD, Rouhani SJ, Peske JD, et al. Structural and functional features of central nervous system lymphatic vessels. Nature 2015;523(7560):337-341. DOI: 10.1038/nature14432

104. Kivisäkk P, Imitola J, Rasmussen S, Elyaman W, Zhu B, Ransohoff RM, et al. Localizing central nervous system immune surveillance: Meningeal antigen-presenting cells activate $\mathrm{T}$ cells during experimental autoimmune encephalomyelitis. Ann Neurol 2009;65(4):457-469. DOI: 10.1002/ana.21379

105. Kaur C, Ling E-A. The circumventricular organs. Histol Histopathol 2017;32(9):879-892. DOI: 10.14670/HH11-881

106. Bill BR, Korzh V. Choroid plexus in developmental and evolutionary perspective. Front Neurosci 2014;8. DOI: 10.3389/fnins.2014.00363 